\title{
Selling Books in Libraries
}

\begin{abstract}
This paper proposes that libraries of the future might sell as well as lend books and journals. This appears to be a natural extension of current practice in supplying Xerox copies. The paper envisions a machine-based catalog of bibliographic information that would produce not only borrowing information but purchasing information as well. The user could then decide what course of action would best meet his needs. New technology would assure that facilities for ondemand hard copy printout would be available.
\end{abstract}

I T IS PROPOSED here to consider the implications of broadening the function of college or university libraries from a place where books may be consulted or borrowed to where they may also be bought. The aim is to provide better service at less total cost.

The suggestion that libraries sell books is less revolutionary than it sounds. A few libraries have had associated bookstores; a few more have sold paperbacks (see Annotated Bibliography A and B). Most make and sell quantities of Xerox copies of journal articles.

Many of us feel some reluctance in facing up to this revolution, but we cannot continue to shut our eyes. At M.I.T. copying in the library has increased a hundredfold in the last fifteen years. We made over a million prints last year and the rate will go up 50 per cent in two years if we follow the predicted national pattern (Annotated Bibliography C).

It is hard to avoid the logic that the next step in this direction should be selling in-print books. Many readers are willing, even eager, to pay for copies

The first draft of this paper was presented as a Working Paper at the Intrex Conference, September 3, 1965. Dr. Locke is Director of Libraries at Massachusetts Institute of Technology. instead of going through the nuisance of charging out and returning books. If libraries were to add a bookstore function and sell in-print books as well as copies of articles, it would pay for itself and save much of the cost of operating the circulation system (at $\$ 1.00$ or so per transaction). It would also mean convenience for users-only one place to go for books-and encouragement toward building up a library of their own.

The rental libraries which were popular thirty or forty years ago were the bookstores' attempt to get into the library business. No one, as far as the author can determine, has made a real try at putting a library into the book business. Limited experiments have been tried, mostly with a sales department under separate management and never with integrated catalog and reading rooms as suggested here.

My proposal is that four types of service be offered in libraries: sale of inprint books and journals, loan of duplicates, sale of copies of out-of-print materials, and, as a last resort, loan of certain single copy items where copying would be too expensive or for some other reason undesirable. Such an operation would hardly be possible on a large scale with manual catalog and inven- 
tory control, but with the availability and decreasing cost of computer assistance it will soon be feasible.

\section{Computer Catalog}

There is already sufficient experience with experimental on-line computer lists and catalogs ${ }^{1}{ }^{\circ}$ to be able to see the way they will work as soon as we can afford them. You communicate with them these days by typing your message. It types out the answer. It remembers everything it has ever been told, except that it completely forgets what it is told to forget. It can take and answer messages over any number of keyboards, i.e., in or out of the library. In its memory we shall put everything in the public cata$\log$, the shelflist, the acquisitions and circulation files but not stop there. Since we are selling books, we shall also put in price and availability information for all items: are they for sale in paperback? in hard covers? in Xerox? can they be borrowed for outside use? Prices and other information are changed as conditions change. It is up to us to keep all the information up to date.

\section{USING THE LIBRARY-BOOKSTORE}

How does the customer get what he wants when he comes into the Librarycum-Bookstore? First let us assume he does not know what he wants. Then he will browse the shelves, or he can use the catalog from conveniently placed keyboards. He will find that the catalog has more flexibility than card trays in that it can retrieve bibliographic information on any criterion or set of criteria, not just author, title, or subject. The catalog will also cover not only monographs, but also technical reports and even recent articles in journals-the total coverage to be determined by the cost of storage and the use patterns of the population served.

\footnotetext{
- Footnotes are given at the end of this article.
}

Once the customer knows what he wants and whether he wants to buy or to borrow it, all he has to do is give the order on the nearest keyboard. The computer types out confirmation of the order or borrowing request, and the customer takes this either to the sales desk where he pays for and gets his book, or to the circulation desk where he gets his loan copy.

The operation is only slightly different for the customer who has found on the shelf something of which he wishes to buy or borrow a copy. Inside the back cover of every item is a magnetic stripe so positioned that it can be read by a reading device associated with the computer keyboards. When any book is presented to this device, the identity of the book is recorded in the computer. The individual can immediately get answers to questions about availability of another copy for loan, price of a copy if it is in stock, price of a Xerox, or instructions on how to proceed if it is desired exceptionally to borrow the shelf copy.

Once the customer has told the computer what he wants, he goes to the sales desk or circulation desk as above. Books reach the desks by conveyor from the print shop, the stock room, or the stacks, as the case may be. Records are kept of all transactions as they occur, so the computer always has a complete inventory, knows where every book is, can reorder sale items as the stock gets low, and keeps complete financial records. (See Bibliography D.)

\section{Storage Space}

It is evident that more storage has to be provided under this system. Sale copies and loan copies have to be stocked in addition to the original on the shelf. The major compensating fact is that the collection always remains intact, or nearly so, whereas in a conventional library the frustration index (per cent of desired books not found) may 
run as high as 50 per cent. Moreover, duplicates for sale or for loan do not occupy prime shelf space.

It is not proposed to carry duplicates of the entire collection. This would be impossible in any large library. Selection policies will have to be laid down for the sale collection and the loan collection. The chief criterion will be probability of demand.

To manage the sales operation a bookman with merchandising experience will be needed. He would determine what books are to be available for sale and how many copies to stock. Libraries in educational institutions have lagged behind public libraries in display techniques which could encourage impulse borrowing. Improvements along these lines would be a dividend from having a merchandising man on the staff. Control will have to be exercised to prevent the building up of sales by stocking expensive books and novelties for the Christmas trade. Only books within the scope of the collecting policy of the library should be sold. Others should be left to the college store or the corner drugstore. Textbooks offer special problems of high volume and seasonality of demand. They should be sold elsewhere. ${ }^{2}$

The computer would keep the merchandising manager informed of the demand rate for loans and sales of individual items, which would be a precious help in deciding what to order and when to reorder. It would provide similar services for the manager of the loan collection, who might be the same person. He would have to watch demand to see what high demand items should be purchased in extra copies.

As to books for course reserve, they will probably have to be serviced separately. They require different conditions of use from the rest of the collections: long hours, restricted circulation, many seats for heavy room use, rapid turn- over. But again sales and Xerox can cut demand.

\section{EQUIPMENT}

In order to offer good service on copies of out-of-print books, we need faster, cheaper ways to copy whole books. It is not difficult to imagine anideal setup, only difficult to get the development work financed. What we need is large scale storage of text in a form which will permit retrieval and transfer of the desired item to paper, preferably printing both sides, folding, binding, and delivery. One attractive possibility is to print on one side of a continuous strip of thin paper, fan fold, and staple. In any case it is essential that delivery be made in a matter of a minute or two even for a whole book. Experience in libraries and bookstores shows that customers want it now. A substantial percentage will not wait. As a service organization, the library should satisfy the largest possible fraction of requests as fast as possible. Speculation as to whether people really need what they ask for or whether they really have to have it now is self-defeating and is often a rationalization of failure.

How practical the above plan for fast reproduction of books turns out to be will depend on the development of a sufficient market for the equipment. High-speed printing, folding and stapling exist, but not input form microfilm or other large scale rapid access forms of storage. Xerox is said to be working in this direction. Others are certain to if there is a market. Let us look at M.I.T. as a sample of the market.

We are a relatively small school and library (7,500 students, a million volumes), yet we copy over a million pages a year. At an average of one hundred pages per book that is ten thousand books. With two hundred working days a year, we would have fifty books a day. For the present we have to conclude 
that our output hardly justifies the equipment described. For the future the picture is different. Our demand has been going up 10 per cent a year. In eight years-and the equipment will not be ready much sooner-our output will double, so we will be doing one hundred books a day even without the added stimulus to demand of high-speed whole book copying. Let us assume that quick availability of whole books would again double demand to two hundred books a day. At two minutes per copy, this means nearly a 100 per cent load factor over a seven-hour day, an efficient operation. Larger libraries will have to have more than one production line or still faster equipment.

Based on experience we shall have to decide which portions of the collection are put into some form of storage for fast reproduction. Certain books, journals, and serials would be processed as they appear or would be purchased in microform. Others would be stored upon receipt of the $\mathrm{n}^{\text {th }}$ request for a copy (the value of " $n$ " to be determined on the basis of experience with that class of material). There will be rare, old, ephemeral, and other material which will never be ready for instant copying.

Tax status will come into question for nonprofit institutions selling books, but that should offer no serious problem. College bookstores are a precedent. Libraries may have to pay taxes on a percentage of their gross, but they should not be frightened by this prospect. They may have to pay royalties on Xerox copies, depending on what copyright legislation is finally passed by Congress. Rather than get into a discussion of this, let us agree that libraries will pay whatever taxes and royalties are legally required as copying methods improve and as the law and its interpretation in the courts evolve. One way or another we shall have to pass the cost on to the user.

Since the above was written there has come to my attention a proposal for a library at the Federal City College in Washington, D.C., written by Catherine Blumenfeld and Robert T. Jordan. It contains ideas similar to Mr. Clark's, mentioned above. This would seem to be another of those cases where an improvement appears in several places when the time is ripe. I hope that others will experiment still further, in the direction envisaged here. High-speed copying has already revolutionized library services. The computerized catalog will add new possibilities. The above proposal for selling books in libraries is another forward step and is presented by the author in the conviction that the future is made of such small steps, not of a complete rupture with the past such as is forecast by those who cry "the Book is dead."

\section{AnNotated Bibliography}

A. Bookstores in Libraries:

1. "Bookstore in Library" by J.E.M. Ontario Library Review, XLVII (November 1963), 146.

Library bookstore since discontinued, not profitable. See 3. below.

2. "Put Bookstores in Libraries, Says Random House President" from the News, Library Journal, XCI (June 1, 1966), 2787-88.

Robert Bernstein said in an interview, "State and local governments could . . . benefit the public by creating bookstores in every public library and school in America."

3. Kirin, Neal, "The Library as a Market Place," Wilson Library Bulletin, XLI (February 1967), 617-21, 641.

Bookstores at the University of North Carolina, at a branch of 
the Toronto Public Library, and the Sales Shop of the New York Public Library are described. The first is apparently no longer a part of the library, and the second has been discontinued. The third is a small sales store analogous to stores in certain museums.

4. Boekenverkoop in openbare bibliotheek; een interview met de bibliothekaris van Hälsingborg (Bookselling in the public library; an interview with the librarian of Hälsingborg) Openbare Bibliotheek, $\mathrm{X}$ (May 1967), 110. Library Science Abstracts, 67/440.

Small book selling operation in kiosk in lobby is economically questionable.

5. Blackburn, Robert T., "College Libraries-Indicted Failures: Some Reasons-and a Possible Remedy," Library-College Journal, reprinted in College \& Research Libraries, XXIX (May 1968), 176.

"Our basic suggestion, then, is to move the bookstore into the library-literally. The library cannot sell its possessions directly, but it could be the best bookstore in the entire world in displaying the titles available. All the library needs to add is an order desk. The student and faculty member simply fill out proper forms (or better, speak the order into a recording device), the library sends it off and notifies the purchaser when his package arrives. ..."

B. Libraries Selling Books:

1. Deale, H. Vail, "Library Sells Paperbounds," Library Journal, LXXIX (December 1, 1954), 229697.
An honor system paperback shop for selected inexpensive paperbacks operated for fifteen years, broke even, now being absorbed into campus bookstore. "I still feel," writes Mr. Deale, "that it's a great idea for the small institution in a community which does not have other outlets."

2. Grohman, Josef, Kniha a společnost (The book and society) Knihovnik, X (No. 3 1965), 65-67. Library Science Abstracts, 15728.

Librarians should overcome their habitual reluctance towards accepting money and sell books as part of their services.

3. “Give-away Paperbacks Predicted For Libraries in the Future" in the News, Library Journal, XCI (August 1966), 3677.

"It is cheaper to give the book away than to go through the cost accounting .... costs about $50 \varnothing$ to return a book ... and about $35 \varnothing$ to give it away." Francis E. Henne, Design for Paperbacks Conference.

\section{Copying in Libraries;}

See "The Determination of Legal Facts and Economic Guideposts with Respect to the Dissemination of Scientific and Educational Information as It Is Affected by Copyright-A Status Report" by Gerald J. Sophar and Lawrence B. Heilprin, of the CICP, published by HEW, USOE Bureau of Research, 1967, Table XIII.

Sixty-six American libraries studied made about $13,165,000$ exposures in 1962 and 20,640,000 in 1966. The same report states (p. 84) "Several independent estimates of total annual copying of published material tend to converge around the following estimates: two billion pages 
copied in the U.S. in 1967, with a forecast of three billion pages in 1969."

This report could more accurately be entitled "Evidence to support the contentions that 1) libraries are widely violating the copyright law, 2) libraries should pay royalties for each copy they produce of a page from a copyrighted work, 3) libraries should pay royalties to a clearinghouse." The initials purport to stand for Committee to Investigate Copyright Problems, but might be read Committee to Inaugurate a Clearinghouse Program, or even Clearinghouse Incorporated for Copyright Payments.

\section{Inventory Control:}

Automation and the Library of Congress, King, G. W. et al., U.S. Government Printing Office, 1963.

Though its cost figures are invalidated by the acceptance of an erroneous assumption concerning the availability of general character recognition equipment, the idea of permanent inventory control of the entire book stock is a good one.

\section{NOTES}

${ }^{1}$ See Reports 1-8, and TIP System Report, October 1967, Technical Information Project, M.I.T. Libraries, Dr. Myer M. Kessler, Director. There also is much in the published literature.

2 The literature on selling books in libraries does not cover one of the most interesting examples. With the permission of Mr. Donald T. Clark, University Librarian of the University of California at Santa Cruz, I quote from a letter in which he describes his experience.

"Early in the development of the Santa Cruz campus ... we concluded . . that student cooperative stores usually did a fair job on supplying textbooks; an excellent job on supplying beer mugs, sweat shirts, pajamas, toothpaste, etc.; but did an extraordinarily poor job in meeting the intellectual appetites of faculty and students. We would like to see on our campus a store which would be directed to meeting these intellectual needs, a store which could create a climate encouraging browsing, development of personal libraries, good reading habits, and the like, a store which would recognize the tremendous change in book publishing brought about largely through the paperback revolution and could have a great assortment of materials readily available for the many students we expect to be engaged in independent study. We also saw this activity as taking some of the heat off our reserve book section....

"Administratively, the bookstore is viewed internally and externally as part of the library. The staff are members of the library staff; they join in all library activities ranging from Christmas parties to the use of the staff lounge. The head of our public services department is the counsellor for selection of materials for stocking in the bookstore. Our acquisitions people are ready to share their knowledge of trade tools, good sources, and understanding of the book trade. We have recently instituted a secondhand section in the bookstore wherein are sold many of our unneeded duplicates. We have not used the bookstore as a source of purchase except under emergency rush conditions.

"I think there is a real potential here and one which makes a lot of sense. With the right kind of personnel I am sure that we can forge ahead. It is an understatement to say that this activity has certainly added a new dimension to my life." 